Review

\title{
Neurokinin-1 Receptor Antagonists against Hepatoblastoma
}

\author{
Miguel Muñoz ${ }^{1, * \mathbb{D}}$, Marisa Rosso $^{1}$ and Rafael Coveñas ${ }^{2}$ \\ 1 Hospital Infantil Virgen del Rocío, Unidad de Cuidados Intensivos Pediátricos, Av. Manuel Siurot s/n, \\ 41013 Sevilla, Spain \\ 2 Institute of Neurosciences of Castilla y León (INCYL), Laboratory of Neuroanatomy of the Peptidergic \\ Systems, University of Salamanca, 37007 Salamanca, Spain \\ * Correspondence: mmunoz@cica.es; Tel.: +34-955012965
}

Received: 18 June 2019; Accepted: 21 August 2019; Published: 28 August 2019

\begin{abstract}
Hepatoblastoma (HB) is the most common malignant liver tumor that occurs during childhood. The prognosis of children with $\mathrm{HB}$ is favorable when a complete surgical resection of the tumor is possible, but for high-risk patients, the prognosis is much worse. New anti-HB strategies must be urgently developed. The undecapeptide substance P (SP) after binding to the neurokinin-1 receptor (NK-1R), regulates cancer cell proliferation, exerts an antiapoptotic effect, induces cell migration for invasion/metastasis, and triggers endothelial cell proliferation for neoangiogenesis. HB samples and cell lines overexpress NK-1R (the truncated form) and SP elicits HB cell proliferation. One of these strategies could be the use of non-peptide NK-1R antagonists. These antagonists exert, in a concentration-dependent manner, an antiproliferative action against $\mathrm{HB}$ cells (inhibit cell proliferation and induce the death of $\mathrm{HB}$ cells by apoptosis). NK-1R antagonists exerted a dual effect in HB: Decreased both tumor volume and angiogenic activity. Thus, the SP/NK-1R system is an important target in the $\mathrm{HB}$ treatment and NK-1R antagonists could act as specific drugs against $\mathrm{HB}$ cells. In this review, we update and discuss the use of NK-1R antagonists in the treatment of HB.
\end{abstract}

Keywords: NK-1 receptor; substance P; hepatoblastoma; aprepitant; antitumor; apoptosis; angiogenesis

\section{Introduction}

Hepatoblastoma $(\mathrm{HB})$ is the most frequent primary malignant liver tumor in children (generally between six months to three years). In western countries, the annual incidence is 1.2 cases per 1 million children [1]. The disease stage is the current key to the patient outcome. The prognosis of children with $\mathrm{HB}$ is favorable in the cases of lower risk, having a five-year event-free survival rate of $80 \%$; however, in the group of high risk, or after relapse, survival decreases by $30-40 \%$ [2]. Unfortunately, for $25 \%$ of the patients with metastasis, overall survival remains extremely poor [3]. Therefore, it is urgent to identify new therapeutic targets and to develop new clinical strategies to improve the HB patient outcome.

It is well known that some peptides and their receptors are involved in cancer. This is the case of the substance P (SP)/neurokinin-1 receptor (NK-1R) system (Figure 1), since SP, via the NK-1R, acts as a universal mitogen in human cancer cells (including HB) (Table 1) [4-6]. SP also exerts an antiapoptotic effect in tumor cells, induces the migration of these cells and elicits neovascularization [4]. Human tumor cells (including HB) overexpress NK-1R, this receptor being involved in the viability of these cells; this means that NK-1R can be considered a new tumor marker [4-6]. This is crucial, since it is also well known that NK-1R antagonists (currently, there are more than 300 compounds: Such as the drug aprepitant, L-732,138, L-733,060) exert multiple antitumor activities (antiproliferative, apoptotic effect, antimigration, antiangiogenesis) [7]. Due to the large amount of data confirming that the SP/NK-1R 
system is involved in cancer, here we review the involvement of this system in the HB development and we also suggest a new therapeutic strategy against HB: The use of NK-1R antagonists.

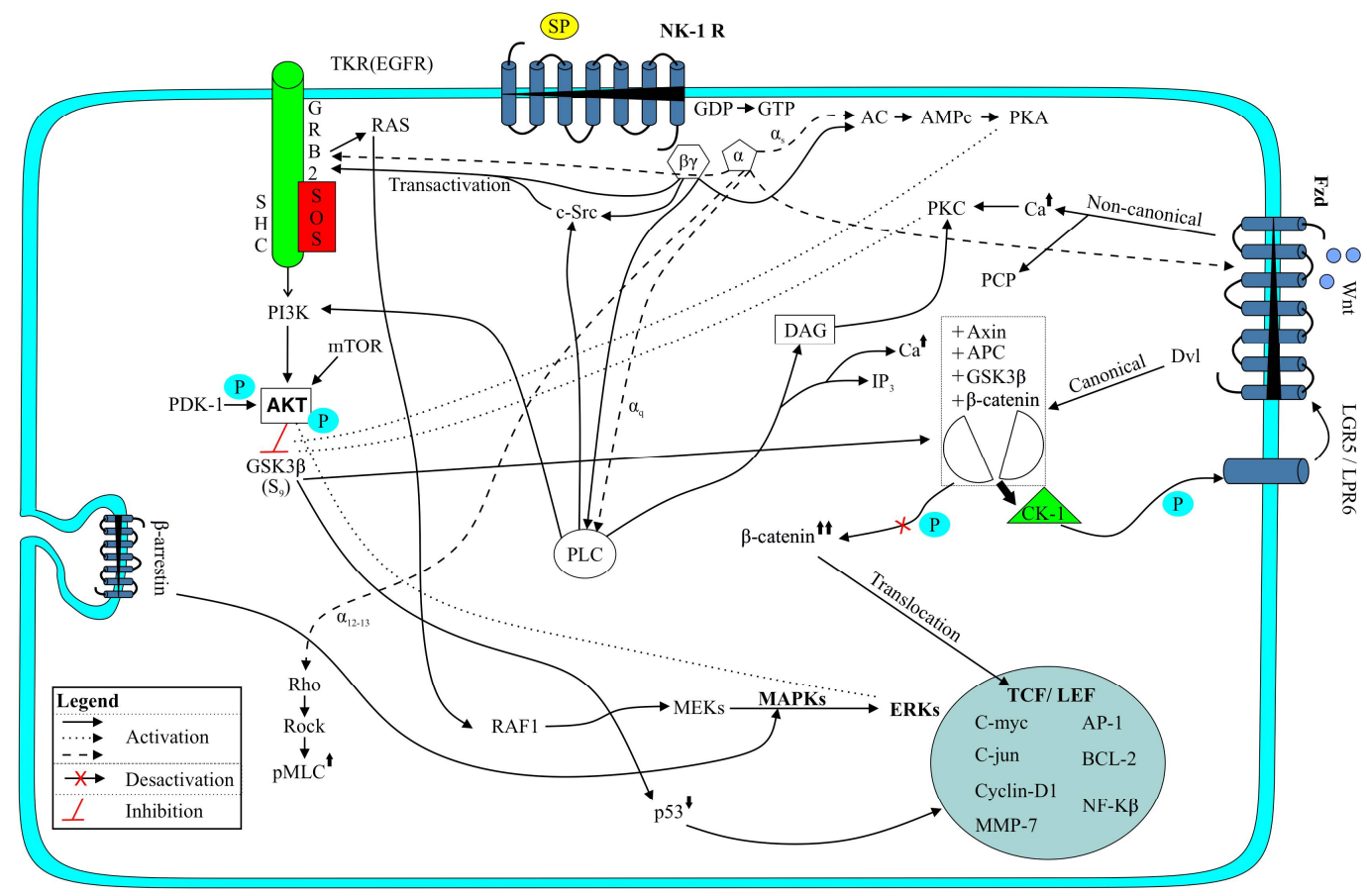

Figure 1. The substance $\mathrm{P} /$ neurokinin-1 receptor $(\mathrm{SP} / \mathrm{NK}-1 \mathrm{R})$ system regulates several cell signaling pathways involved in cancer progression. These pathways are the following: (a) Antiapoptotic signaling pathway (PI3K/Akt/mTOR); (b) cell proliferation signaling pathway (PKC, MAPKs, ERK); (c) cell migration signaling pathway (Rho-ROCK-pMLC); (d) Wnt signaling pathway ( $\beta$-catenin, c-myc, cyclin D1); (e) AC-cAMP-PKA phosphorylation signaling pathway, and (f) the Warburg effect (GSK-3 $\beta$ ). APC: Adenomatous polyposis coli; Dvl: Dishevelled; Fzd: Frizzled receptor; PCP: Planar cell polarity pathway; PDK-1: Phosphoinositide-dependent kinase-1; pMLC: Myosin light-chain kinase; TCF/LEF: Transcription factor/lymphoid enhancer-binding factor.

Table 1. The SP/NK-1R system in human HB cell lines (HepT1; HepG2; HuH6).

\begin{tabular}{|c|c|}
\hline \multirow{3}{*}{ NK-1R } & Express mRNA for the NK-1R \\
\hline & Expression of the TAC1R gene is increased \\
\hline & $\begin{array}{l}\text { Express full and truncated isoforms of the NK-1R. The HB cells express essentially the } \\
\text { truncated form. Expression of the full form is higher in non-tumor cells }\end{array}$ \\
\hline SP & A universal mitogen (at nanomolar concentration) of tumor cells, including HB cells \\
\hline \multirow{7}{*}{$\begin{array}{l}\text { Non-peptide } \\
\text { NK-1R antagonists }\end{array}$} & $\begin{array}{l}\text { Antiproliferative action in a concentration-dependent manner: The higher the } \\
\text { concentration, the greater the antitumor activity }\end{array}$ \\
\hline & $\begin{array}{l}\text { Induce cell death by apoptosis, cleavage of caspase-3and proteolysis of poly } \\
\text { (ADP-ribose) polymerase }\end{array}$ \\
\hline & Aprepitant $\left(\mathrm{IC}_{50}\right)$ for HepT1 $(31.1 \mu \mathrm{M})$, HuH6 $(33.18 \mu \mathrm{M})$, HepG2 $(38.61 \mu \mathrm{M})$ \\
\hline & L-732,138 $\left(\mathrm{IC}_{50}\right)$ for HepT1 $(42 \mu \mathrm{M})$, HuH6 $(41 \mu \mathrm{M})$, HepG2 $(110 \mu \mathrm{M})$ \\
\hline & L-733,060 (IC 50$)$ for HepT1 $(15 \mu \mathrm{M})$, HuH6 $(14 \mu \mathrm{M})$, HepG2 $(17 \mu \mathrm{M})$ \\
\hline & Co-administration of aprepitant and cytostatics exerts a synergistic antitumor effect \\
\hline & $\begin{array}{l}\text { Pretreatment of non-tumor cells (human embryonic kidney (HEK)-293) with aprepitant, } \\
\text { protected these cells from cytostatic toxicity }\end{array}$ \\
\hline
\end{tabular}




\section{The SP/NK-1R System}

The undecapeptide SP, hemokinin-1, neurokinin A and B belong to the tachykinin peptide family and, via NK-1R, NK-2R and NK-3R, many physiological actions are exerted: NK-1R shows a preferential affinity for SP/hemokinin-1, NK-2R for neurokinin A and NK-3R for neurokinin B [7]. The NK-1R protein is encoded by the TACR1 gene (located in chromosome 2); the receptor belongs to the 1 (rhodopsin-like) $\mathrm{G}$ protein-coupled receptors family (also known as 7TM receptors, seven-transmembrane domain receptors or serpentine receptors) and can be coupled to several groups of $G$ proteins: $G \alpha i, G \alpha$ s and $\mathrm{G} \propto \mathrm{q}$ (Figure 1) [8,9]. The activation of a determined $\mathrm{G}$ protein is regulated by the conformation of the receptor as well as the type of ligand $[10,11]$. The $G$ proteins differ in their signaling pathway/effectors that they activate (Figure 1) [12]. Thus, the coupling of NK-1R with the Gai protein inhibits activity of the adenylate cyclase and decreases the level of cyclic adenosine monophosphate [13,14], whereas coupling of NK-1R with the G $\alpha$ s protein activates the adenylate cyclase, the production of cyclic adenosine monophosphate, the activation of the protein kinase $\mathrm{A}$ and the phosphorylation of specific substrates (Figure 1) [15]. The coupling of NK-1R with the G $\alpha$ q protein promotes the activation of phospholipase $C \beta$, an increase in the phosphatidylinositol-3 kinase, the release of diacylglycerol and an increase in the intracellular level of $\mathrm{Ca}^{++}$(Figure 1) [16]. Through these pathways, the transcription of specific genes is regulated.

Seven-transmembrane-helix receptors share the same structural unit (Figure 1): An amino-terminal extracellular domain (responsible for the specificity of the receptor), a carboxy-terminal cytoplasmic domain (the carboxy-terminal conserved domain of tachykinins (Phe-X-Gly-Leu-Met- $\mathrm{NH}_{2}$ ) interacts with the receptor), and three extracellular (EL1, EL2, EL3) and intracellular (C1, C2, C3) loops flanked by seven intermembrane domains [17]. The second and third loops are involved in the binding of the SP agonists to residues 178-183 (Val-Val-Cys-Met-Ile-Glu) located in the middle of the second extracellular loop (EL2): A covalent link occurs between SP and the methyl group of a methionine residue (Met-181) [18]. The third cytoplasmic loop (C3) is responsible for the binding to protein $\mathrm{G}$. The C-terminus contains serine/threonine residues, which once phosphorylated, cause desensitisation/internalization of the receptor, the latter being recycled to the plasma membrane [19]. Internalization of the NK-1R depends on the concentration of SP: Low concentration, the receptor is internalized and quickly recycled to the plasma membrane but, at high concentration, the mechanism is slower (endocytosis into endosomes) [20]. Moreover, it has been reported that the loss of certain $C$-terminal serine/threonine residues is important for the $G$ protein-coupled receptor kinase interaction and $\beta$-arrestin recruitment for subsequent receptor internalization (Figure 1) [21].

Two isoforms of NK-1R have been reported: The truncated (tr-NK-1R) and the full-length (fl-NK-1R) [6,22,23]. The first contains 311 amino acids (at the C-terminus, the last 96 amino acids are lost: A premature stop codon does not allow that intron between exons $4 / 5$ to be removed) [12] and the second one has 407 amino acids. The loss of the last 96 amino acids has been related to a loss of internalization [24]. The tr-NK-1R is able to prolong the responses after the binding of the ligands (due to the absence of a rapid desensitization) and, due to the different structure of both isoforms, it seems that they have a different functional significance, differing in cell signaling capability [25]. The tr-NK-1R promotes a rapid and sustained $\mathrm{Ca}^{++}$response [24].

The presence of NK-1R has been reported in many human cancer cell lines/tissue samples and, after application of a knockdown gene-silencing method, it has been demonstrated that NK-1R plays a crucial role in the viability of tumor cells $[5,26]$. It seems that the degree of malignancy of a tumor correlates with the number of NK-1Rs: Greater number, higher malignancy [27] and that a poorer prognosis correlates with NK-1R overexpression [4,28]. Moreover, it is known that in malignant tissues the expression of NK-1R mRNA increased, but not in the benign tissues [27,29].

SP and the NK-1R have been observed in HB samples and the NK-1R in human HB HepT1, HepG2 and HuH6 cell lines; these three cell lines expressed mRNA for the NK-1R, and it is known that the expression of the TAC1R gene was increased approximately by 7.5-30 fold in HB cell lines compared to fibroblasts (Tables 1 and 2) [6]. It is important to note that the above human HB cell lines expressed 
both isoforms of the NK-1R (fl-NK-1R and tr-NK-1R), but human HB HuH6, HepT1 and HepG2 cell lines expressed essentially tr-NK-1R and, in comparison to these cell lines, the fl-NK-1R expression was highest in the human embryonic kidney (HEK)-293 cells and human fibroblasts (Table 1) [6]. By contrast, the latter two cells showed a reduced number of the tr-NK-1R form [6]. It is important to note that the HEK-293 cells and fibroblasts, when studying cell survival, showed the strongest resistance to aprepitant [12]. This suggests that the action of the NK-1R antagonists is related to the differential expression of the NK-1R [12]. Moreover, it seems that the tr-NK-1R form remains up-regulated and activated continuously (as indicated above, it seems that this isoform is not internalized) and for this reason the tr-NK-1R isoform has been linked to cancer progression [25]. It has also been reported that the expression of the full-length isoform was inversely associated with proliferation, invasiveness and metastasis and that the overexpression of the tr-NK-1R isoform promotes a malignant transformation of cells, tumor progression and metastasis [30]. It is also important to note that in patients with cancer, compared to healthy subjects, the level of SP in the serum was higher [31] and that the level of the undecapeptide was $>7$-fold in cultured cancer cells than in cultured normal epithelial cells [29]. Finally, in 47 children with $\mathrm{HB}$, it was reported that the tr-TACR1 isoform was expressed ubiquitously among the different subsets of HB (Table 2). This finding is also important since the NK-1R may serve as a therapeutic target in HB patients, independent of the clinical stage/tumor biology [32]. Moreover, the tr-TACR1 was more expressed in children with HB than in non-tumor controls, but the expression of the fl-TACR1 showed no difference between the two groups [12]. Thus, it seems that the tr-NK-1R but not the fl-NK-1R is associated with cancer [12].

Table 2. The SP/NK-1R system in the human HB sample and tumor.

\begin{tabular}{cll}
\hline \multicolumn{1}{c}{ Items } & HB Sample & \multicolumn{1}{c}{ HB Tumor } \\
\hline SP/NK-1R system & $\begin{array}{c}\text { Expression of both } \\
\text { SP and NK-1R }\end{array}$ & $\begin{array}{l}\text { Truncated-TACR1 isoform is expressed ubiquitously among the } \\
\text { different subsets of children with HB }\end{array}$ \\
\hline $\begin{array}{l}\text { Non-peptide } \\
\text { NK-1R antagonists }\end{array}$ & $\begin{array}{l}\text { In experimental animals: Dual effect of aprepitant }(80 \mathrm{mg} / \mathrm{kg} / \mathrm{day} \\
\text { for 24 days). The antagonist decreased the tumor volume (tumor } \\
\text { cells die by apoptosis) and the angiogenic activity (decrease of } \\
\text { the vascularized area, but not the microvascular density). } \\
\text { Aprepitant lowered the tumor-specific alpha-fetoprotein serum } \\
\text { level and decreased the number of Ki-67 positive cells }\end{array}$ \\
\hline
\end{tabular}

\section{Involvement of the SP/NK-1R System in HB Progression}

SP, via the NK-1R, acts as a universal mitogen in normal and tumor cells (e.g., HB, neuroblastoma, melanoma, retinoblastoma, glioma, osteosarcoma) (Table 1) [5,6,33]. In tumor cells, SP promotes c-myc mRNA and protein synthesis, c-myc being crucial for the progression through the $S$ phase to G2/M in the cell cycle (Figure 1) [34,35]. It has been reported that c-myc is necessary to sustain a rapid tumor growth [36]. SP, via NK-1R, promotes the formation of an activated epidermal growth factor receptor (EGFR) complex, induces the transactivation of EGFR, activates the mitogen-activated protein kinase (MAPK) pathway, induces the activation of extracellular signal-regulated kinase (ERK)2, and the synthesis of DNA occurs (Figure 1) [37]. According to these data, it seems that the signaling pathways between the NK-1R and growth factors (e.g., EGFR) converge at an upstream point, favouring the pathways by which SP regulates cell proliferation [37]. It is known that c-Src interacts with EGFR inducing its phosphorylation and that the increased activity/overexpression of c-Src is related to cancer progression (Figure 1), since its interaction with EGFR/Her2 enhances mitogenic signaling pathways [38].

SP is synthesized/secreted by non-tumor and tumor cells; it can be released from the tumor mass into blood vessels and/or released from nerve terminals (this is important since SP regulates tumor growth and this means that an interaction between cancer cells and the nervous system occurs) [4,7]. Since several years ago, the involvement of the SP/NK-1R system in cancer (e.g., 
melanoma, retinoblastoma, glioma) $[4,5,7]$ is known; however, there are few original data on the involvement of this system in HB (Tables 1 and 2). In fact, only one review [12] and two research papers $[6,32]$ have been currently published on the field. Thus, there are many scientific questions to be solved in the future on the involvement of the SP/NK-1R system in HB (Table 3). SP has been observed in the HB samples; the undecapeptide (at nanomolar concentration) promotes the proliferation of the HB cell lines (HepT1, HepG2, HuH6) and NK-1R antagonists (e.g., aprepitant, L-732,138, L-733,060) counteract the mitogenic action exerted by SP (Tables 1 and 2) [6]. SP, via the NK-1R, promotes the DNA synthesis in cancer cells, activating members of the MAPK family (p38MAPK, ERK1/2) (Figure 1) [34]. Then, ERK1/2 is translocated into the nucleus, promoting cell proliferation and exerting an antiapoptotic effect [21].

Table 3. Key points in future HB research.

\begin{tabular}{|c|c|}
\hline \multirow{8}{*}{ NK-1R } & NK-1R: A new HB tumor marker \\
\hline & NK-1R: Therapeutic target in HB patients, independent of the clinical stage/tumor biology \\
\hline & NK-1R: Involved in the viability of HB cells? \\
\hline & The tr-NK-1R, but not the fl-NK-1R, is associated with cancer? \\
\hline & $\begin{array}{l}\text { The response of the NK-1R antagonists depends on the differential expression of the } \\
\text { receptor (truncated/full)? }\end{array}$ \\
\hline & tr-NK-1R: Responsible for a constitutive growth stimulus in the HB cells? \\
\hline & Overexpression of the tr-NK-1R: Correlates with poorer prognosis and advance HB stages? \\
\hline & $\begin{array}{l}\text { tr-NK-1R: Not internalized in the HB cells? Involved in the malignant transformation of } \\
\text { the HB cells? }\end{array}$ \\
\hline \multirow{4}{*}{ SP } & Level of SP in the serum of HB patients \\
\hline & SP activates GSK-3 $\beta$ in the HB cells (Warburg effect)? \\
\hline & SP is released from the HB cells to promote neovascularization? \\
\hline & SP triggers the migration of HB cells? \\
\hline
\end{tabular}

\subsection{PI3K/Akt/mTOR Signaling Pathway}

This pathway is involved in cell proliferation and survival and it is activated via the receptor tyrosine kinase, which can be activated by cytokines or the epidermal growth factor (Figure 1) [12]. The activation of this pathway (crucial to drug resistance) promotes the activation, through phosphorylation, of many intracellular proteins. In experimental animals, it has been reported that the inhibition of mTOR affects the $\beta$-catenin/Yes-associated protein 1-induced HB development and growth [39]. The antiapoptotic effect of SP has been demonstrated in many cells (e.g., macrophages, neutrophils, thymocytes) and it is known that SP increases the phosphorylation and activity (via PI3K) of Akt (protein kinase B) (Figure 1); this activation suppresses apoptosis [11,21,40,41]. In macrophages, SP activates the PI3K/Akt/mTOR/S6kinase pathway [42], the activation of the PI3K/Akt/mTOR pathway being crucial for the HB survival. Most tumors express p-GSK-3 $\beta$, p-Akt and p-mTOR and some of them show a significant expression of cyclin D1, p21, and p27.

It has been demonstrated that the inhibition of PI3K diminished the HB cell growth, this being accompanied by a reduced phosphorylation of both GSK-3 $\beta$ and Akt (Figure 1). The inhibition of PI3K increases the HB apoptosis and decreases the HB cellular proliferation, this being linked to increased p27 and reduced cyclin D1 levels [43]. In human HB HepT1, HepG2 and HuH6 cell lines, it has been reported that the Akt signaling pathway is a target of aprepitant [44]. After blockage of the NK-1R with aprepitant, both phosphorylation sites (S473, T308) of Akt and mTOR (S2448) become increasingly phosphorylated (that is, an activation of upstream Akt/mTOR signaling occurs), whereas downstream components of Akt/mTOR (4E-BP1/2, p70S6K) are downregulated [12,44]. In the nucleus of the HB cells and after administration of aprepitant, the presence of phosphor-Akt (S473) and 
phosphor-mTOR (S2448) has been reported [12]. In the nucleus, Akt can phosphorylate intracellular components promoting DNA repair/cell survival [45]. It has been suggested that the activation of Akt could be related to a cellular mechanism that avoids cell death and contributes to drug resistance, attenuating the antitumor efficacy of aprepitant $[12,46,47]$. This could explain why, in experimental animals, although aprepitant significantly reduced the volume of the HB tumor, a slight increase of the volume was observed after twenty days of treatment [6,12]. In summary, the data suggest that the $\mathrm{PI} 3 \mathrm{~K} / \mathrm{Akt} / \mathrm{mTOR}$ signaling pathway (Figure 1) plays a crucial role in the HB growth inhibition exerted by NK-1R antagonists.

\subsection{Wnt Signaling Pathway}

This pathway plays an important role in survival, differentiation and cell proliferation (Figure 1) [12]. In most $\mathrm{HB}$, missense mutations/exon-3 deletions in gene coding for $\beta$-catenin (a downstream effector of the Wnt signaling pathway) have been reported and HB has been associated with an aberrant activation of the $\beta$-catenin pathway (Figure 1$)[3,36]$. The Wnt pathway is activated via inhibition of the $\beta$-catenin degradation; thus, the level of $\beta$-catenin is increased and then the protein is translocated into the nucleus promoting cell proliferation (Figure 1) [12]. Wnt3a is reported to activate the ERK pathway through Ras, Raf and mitogen-activated protein kinase kinase (MEK); that it is involved in cellular proliferation, and that it activates p38MAPK which is crucial for the accumulation of $\beta$-catenin (this accumulation promotes tumorigenesis) (Figure 1) [48]. Wnt signaling has been reported as corroborating an active canonical Wnt signaling and it is known that SP activates the Wnt signal transduction pathway and enhances the proliferation of stem cells (Figure 1) [49,50]. Wnt signaling is involved in the SP inhibition of apoptosis. SP exerts a protective effect, reduces the apoptotic rate, produces nuclear condensation and the activation of caspase- 3 and caspase- 9 . The inhibition of Wnt signaling or NK-1R antagonists blocked this effect. SP promotes the mRNA and protein expression of Wnt signaling molecules such as $\beta$-catenin, GSK-3 $\beta$, c-myc and cyclin D1 (Figure 1) [51].

In human HB HepT1, HepG2 and HuH6 cell lines treated with aprepitant, it has been demonstrated that the Wnt and Akt signaling pathways are the targets of NK-1R antagonists [44]. Aprepitant inhibited the canonical Wnt pathway (evidenced by the decrease of $\beta$-catenin and the downregulation of the Wnt target genes AXIN2 and LGR5) (Figure 1); it decreased the phosphorylation of 4E-BP1/2 and p70S6K, and it decreased the growth of the HB cells [44]. Aprepitant is also involved in the downregulation of FOXM1 (a protein involved in the translocation of $\beta$-catenin into the nucleus) [12,52]. It seems that the inhibition of the Wnt pathway is strengthened by the FOXM1- $\beta$-catenin complex disruption, enhancing growth arrest and apoptotic mechanisms [44]. It is also important to note that aprepitant decreased stemness property/canonical Wnt signaling in Wnt-dependent cancer stem cells [12]. This is extremely important because it seems that cancer stem cells are involved in tumor relapse/resistance [53].

\section{NK-1R Antagonists as Anti-HB Drugs: Mechanisms of Action and Therapeutic Properties}

There are peptide and non-peptide NK-1R antagonists. Peptide NK-1R antagonists are degraded by peptidases, they are not brain-penetrant and some of them exert toxic effects, but non-peptide NK-1R antagonists (e.g., rolapitant (Varubi), aprepitant (L-754,030, MK-869, Emend), GR-205,171 (Vofopitant), CP-96,345, WIN-51,708, L-733,060, L-732,138) are not degraded by peptidases and they can cross the blood-brain barrier [7]. Thus, non-peptide NK-1R antagonists show more therapeutic advantages than peptide NK-1R antagonists which are toxic and unstable [54]. Only three NK-1R antagonists (non-peptide) have been approved for humans: Aprepitant, its pro-drug (fosaprepitant, MK-0517, L-758,298, Ivemend) and rolapitant (Varubi). SP binds to the extracellular loops of the receptor, but non-peptide NK-1R antagonists (lipid soluble) bind more deeply [55]. It is important to note that the therapeutic action of non-peptide NK-1R antagonists, after binding to the fl-NK-1R or the tr-NK-1R isoforms, is similar because such action is not associated with the intracellular C-terminus. Non-peptide NK-1R antagonists (e.g., aprepitant (morpholine derivative), L-733,060 
(benzyletherpiperidine), L-732,138 (tryptophan-based)) are broad spectrum antitumor compounds that exert an antitumor action against many human cancer cells (e.g., HB, neuroblastoma, glioma, melanoma, retinoblastoma, acute lymphoblastic leukaemia B and T cells, gastric, colon, breast, larynx and pancreatic carcinoma) (Table 1) $[4,6]$. The antitumor action exerted by these antagonists is in a concentration-dependent manner: The higher the concentration, the greater the antitumor activity (Table 1) [4,6].

\subsection{Antiproliferative Effect}

Human HB cells overexpress the NK-1R (truncated form) and NK-1R antagonists (L-733,060, L-732,138, aprepitant) after binding to the NK-1R, exerting an antiproliferative action against the HB cells lines (HepT1, HuH6, HepG2) (Table 1) [6]. Thus, the IC 50 of aprepitant for HB HepT1, HuH6 and HepG2 cells were $31.1 \mu \mathrm{M}, 33.18 \mu \mathrm{M}$, and $38.61 \mu \mathrm{M}$ respectively; $42 \mu \mathrm{M}, 41 \mu \mathrm{M}$, and $110 \mu \mathrm{M}$ (for L-732.138), and $15 \mu \mathrm{M}, 14 \mu \mathrm{M}$, and $17 \mu \mathrm{M}$ (for L-733,060) (Table 1) [6]. It seems that this effect is due to the blockade of the MAPK cascade (including p38MAPK and ERK1/2 signaling). It is known that SP, through the G-protein $\beta \gamma$ subunit, which recruits components of the Ras-dependent cascade (e.g., SHC, GRB2, Src), leads to the activation of Raf-1 and MAPK 1, a specific activator of ERK1/2 (Figure 1) [56]. Thus, NK-1R antagonists could counteract this pathway. In a HuH6 xenograft mouse model $(80 \mathrm{mg} / \mathrm{kg} /$ day aprepitant for 24 days), reduction of tumor growth (reduced tumor volume and weight) was reported along with a lowered tumor-specific alpha-fetoprotein (a marker of HB) serum level and a decreased number of Ki-67 positive cells (Table 2) [6]. In this model, NK-1R antagonists induced a dual effect: Decreased the volume of the tumor (tumor cells die by apoptosis, see below) and exerted an antiangiogenic effect (Table 2) [6].

\subsection{Apoptotic Effect}

NK-1R antagonists (L-733,060, L-732,138, aprepitant) promoted apoptosis in human HB HepT1, HuH6 and HepG2 cell lines (Table 1) [6]. Moreover, in HB, NK-1R antagonists increased the percentage of cells with subdiploid DNA features of apoptotic death; caused the cleavage of caspase- 3 and the proteolysis of poly (ADP-ribose) polymerase (Table 1) [6]. This same NK-1R antagonist is known to promote apoptosis in many other tumor cells [4] and the blockade of this receptor by L-733,060 caused the cleavage of caspase- 3 and the proteolysis of poly (ADP-ribose) polymerase, increased apoptosis and inhibited the basal kinase activity of Akt [57]. In the Akt phosphorylation mediated by the NK-1R, the full involvement of PI3K/the non-receptor tyrosine kinase Src was reported as well as the partial involvement of EGFR and the non-involvement of MAPK/ERK (Figure 1) [57]. It is known that the expression of the NK-1R is pivotal for the survival of cancer cells. By eliminating the expression of this receptor in cancer cells, due to apoptotic mechanisms, a decrease in the number of these cells has been reported and it is also known that in tumor cells the application of the siRNA TAC1R method decreased the levels of p-EGFR, p-Akt and p-ERK (Figure 1) [5,26,58].

\subsection{Anti-Warburg Effect}

In order to obtain energy, cancer cells show a high rate of glycolysis (200 times higher than those of their normal tissues of origin) followed by lactic acid fermentation (Warburg effect) [4,59]. In cancer cells, SP (via the NK-1R) increases the concentration of intracellular $\mathrm{Ca}^{++}$(Figure 1), induces the breakdown of glycogen and then, due to the glucose obtained, these cells increase their metabolism; however, NK-1R antagonists block such a breakdown and cancer cells die from starvation [60]. The glycogen synthase is involved in glycogenesis, whereas glycogen synthase kinase-3 (GSK-3ß) (Figure 1) inactivates the glycogen synthase and produces glucose. It has been reported that GSK- $3 \beta$ is linked to poor prognostic/cancer progression and that the inhibition of GSK-3 $\beta$ suppresses tumorigenesis by attenuating cell proliferation, while increasing apoptosis and restraining cell motility [61,62]. Inhibitors of GSK-3 $\beta$ reduce glucose output and increase the synthesis of glycogen from L-glucose, counteracting the Warbur effect and it is also known that SP activates GSK-3 $\beta$ and that NK-1R antagonists inhibit 
GSK-3 $\beta$ activity [57]. The previous data suggest that NK-1R antagonists could counteract the Warburg effect by inhibiting the GSK-3 $\beta$ activity in HB cells. This must be confirmed in future studies (Table 3).

\subsection{Antiangiogenic Effect}

Neoangiogenesis is crucial in advanced stages of the inflammatory process and in tumor growth development, this being associated with an increased innervation of the tissue and an overexpression of the NK-1R $[4,28]$. The increased level of SP found in chronic inflammatory conditions plays an important role in the development of new vessels [63]. Infiltrating immune cells express SP and NK-1R and the peptide exerts a pro-inflammatory action [12,64]. It is well known that the blood vessels located in the tumor/peritumoral region express both SP and NK-1R [28]. The SP/NK-1R system is involved in the proliferation of endothelial cells, followed by the formation of blood vessels (increasing vascularization) and by an increase in blood flow and hence neovascularization is crucial for the growth of the tumor mass [65]. However, NK-1R antagonists block such proliferation $[4,66]$.

It has been reported that SP promotes the release of IL-1, IL-6, IL-10, IL-12 and TNF $\alpha$ from inflammatory cells; that SP controls both secretion and gene expression of the vascular endothelial growth factor (VEGF, a pro-angiogenic factor involved in many inflammatory diseases); that this secretion increased when SP and IL-33 were co-administered, and that NK-1R antagonists inhibited the previously mentioned effects exerted by SP [67]. Moreover, it is known that calcium-dependent protein kinase $\mathrm{C}$ isoforms, ERK, c-jun N-terminal kinases (JNK) and MAPKs are involved in the production of the VEGF regulated by SP [67]. SP is expressed in human HB tumors [6]. This suggests that via a paracrine action, the SP released from the HB cells could favor the vascularization of the HB tumor by stimulating, via the NK-1R expressed in endothelial cells, the proliferation of these cells. This paracrine action must be confirmed in future studies.

In a human pancreatic xenograft model, it has been demonstrated that a peptide NK-1R antagonist blocked the growth of the tumor by antiproliferative and antiangiogenic mechanisms [68]. This was also observed in a HB xenograft nude mouse model [6]. Thus, aprepitant blocked the HB growth by inhibiting both HB cell proliferation and angiogenesis (Table 2): A decrease of the vascularized area was observed, but not of the microvascular density [6]. The finding confirms that NK-1R antagonists counteract angiogenesis in HB.

\subsection{Antimetastatic Effect}

In advanced stages of $\mathrm{HB}$, invasion and metastasis occur and unfortunately for $25 \%$ of the patients with $\mathrm{HB}$ metastasis, the overall survival remains poor [3]. Membrane blebbing plays an important role in cell movement/spreading and in tumor cell infiltration/invasion [69]. It is known that SP promotes the migration of tumor cells (SP favors the formation of membrane blebbing) for invasion/metastasis; that SP increased the expression of VEGF-C and matrix metalloproteinase favoring tumor metastasis; that NK-1R antagonists inhibit such an increase [70,71], and that these antagonists block the changes in the cell shape (including blebbing) induced by SP (in the latter mechanisms Rho-associated protein kinase (ROCK) was involved) (Figure 1) [72]. In tumor cells (but not in non-tumor cells), SP induced the phosphorylation of p21-activated kinase and augmented the phosphorylation of the myosin regulatory light chain kinase [73]. Moreover, the loss of the EGFR-ASAP-1 signaling has been reported to be an important characteristic of invasive/undifferentiated HB [74].

Since the HB cells express both SP and the NK-1R [6], it is possible that the peptide could trigger the migration of the HB cells for invasion/metastasis and that it could be blocked by NK-1R antagonists. This must be confirmed in the future (Table 3).

\subsection{Combination Therapy Using NK-1R Antagonists}

In HB patients, the high-risk group is characterized by a marked chemoresistance and poor outcome [75]. Multidrug resistance often occurs after four cycles of chemotherapy [12]. In clinical practice, the main goal of the combination therapy is to increase the therapeutic effects (additive 
or synergistic) of a drug. In $\mathrm{HB}$, the adjuvant chemotherapy regimens include cisplatin (induces ototoxicity/nephrotoxicity) [76], doxorubicin (DOX) (induces cardiotoxicity) [77] and microtubule destabilizing agent (MDAs, e.g., vinorelbine, vincristine) treatments. In human HB HepT1, HuH6 and HepG2 cell lines, it has been demonstrated that aprepitant and cytostatics showed a synergistic effect (Table 1) [6]. In HepT1 cells, a synergistic effect for DOX/aprepitant was found, but this effect was not observed in the case of cisplatin/aprepitant [6]. In HepG2, a synergistic effect was found for aprepitant/DOX or cisplatin [6]. Even the effects of aprepitant/DOX (low-dose) were significantly higher when compared to the treatment with single compounds. In HuH6, similar results were obtained [6]. These data suggest that in HB patients aprepitant, in combination therapy with the above-mentioned drugs, could exert a synergistic therapeutic effect. Moreover, it has been demonstrated that pre-treatment of non-tumor HEK-293 cells with a NK-1R antagonist (before exposure to cytostatics), protected the HEK-293 cells from cytostatic toxicity (Table 1) [33].

Treatment with DOX is known to elicit cardiotoxicity [77] and that the SP/NK-1R system mediates this DOX cardiotoxicity. In tumor cells, the treatment with aprepitant increased cell death by apoptosis, reactive oxygen species synthesis and DOX-induced reduction of cell viability, whereas in cardiomyocytes treatment with the same drug decreased apoptosis, reactive oxygen species synthesis and DOX-induced reduction of cell viability [78].

NK-1R antagonists and MDAs exert a synergic effect. MDAs trigger apoptotic signaling through JNK, and the modulation of the MAPK pathway can inhibit or enhance the apoptosis induced by MDAs. It seems that NK-1R antagonists sensitizes tumor cells to the MDA-mediated inhibition of cell viability by reducing the anti-apoptotic NK-1R signaling, thus enhancing the cell death induced by MDAs [79]. This combination is synergistic for the growth inhibition of cancer cells expressing the NK-1R, but not for non-cancer cells. Moreover, the combination therapy of NK-1R antagonists/cytostatics decreases the toxicity/side-effects of chemotherapy and it is less toxic than treatments with chemotherapy alone [79]. In summary, the strategy suggested might be clinically useful for those patients with cancer (e.g., HB) that must be treated with chemotherapy (Table 3).

Recently, a case report has been published on a patient with lung cancer that was treated with a combination therapy of aprepitant $(1140 \mathrm{mg} /$ day) and radiotherapy [80]. The patient was treated for 45 days and, six months after treatment, the tumor mass had disappeared [80]. Three years after the treatment, the patient died due to causes not related to cancer [80]. More studies must be performed to test combination therapy strategies. In addition, it is important to test the antitumor action of aprepitant when administered alone (it has been suggested $25 \mathrm{mg} / \mathrm{kg} /$ day, for a long period of time according to the response of the treatment) (Table 3) [81].

\section{Safety Profile and Side-Effects of NK-1R Antagonists}

Contrary to cytostatics, NK-1R antagonists at antiemetic doses do not produce serious side-effects, although headaches, hiccupping, vertigo and drowsiness have been reported after administration of these antagonists [82,83]. In patients with moderate to severe depression the safety of aprepitant was reported: A dose of $300 \mathrm{mg} /$ day was tolerated very well while no statistically significant difference in the frequency of adverse events was observed as compared to the placebo [84]. The safety of aprepitant against human fibroblasts has also been demonstrated: The $\mathrm{IC}_{50}$ for tumor cells (HB HepT1, HuH6, and HepG2 cell lines were $28.5 \mu \mathrm{M}, 31.1 \mu \mathrm{M}$ and $33.18 \mu \mathrm{M}$, respectively) was lower than that for fibroblasts $(57.5 \mu \mathrm{M})$ [6]. In addition, the safety of aprepitant against lymphocytes has been recently reported $\left(\mathrm{IC}_{50} 176.2 \mu \mathrm{M}\right)$ [85].

As mentioned above, a patient with lung cancer was treated for 45 days with aprepitant (1140 mg/day) [80]. No side-effects were observed [80]. In this case report, the safety of aprepitant was demonstrated since no biochemical analytical alteration was observed and the patient showed very good general health, including weight gain [80]. This means that aprepitant is safe at the high dose necessary for the HB treatment ( $25 \mathrm{mg} / \mathrm{kg} /$ day) [81]. 


\section{Conclusions}

According to the data reported in previous sections, Table 3 shows the key-points in future HB research. Altogether, data show that NK-1R is a new therapeutic target for the treatment of HB because NK-1R antagonists (e.g., aprepitant) exert an antitumor effect (antiproliferative, apoptosis, tumor volume is decreased) against HB cells (they overexpress the NK-1R (truncated form) and the receptor must be used as a tumor marker). In addition, NK-1R antagonists decreased the angiogenic activity in HB. This means that NK-1R antagonists exert a dual antitumor action in HB: Antiproliferative and antiangiogenic, and that the SP/NK-1R system plays an important role in the tumor microenvironment. In HB patients, the NK-1R may serve as a therapeutic target, independent of the clinical stage. The tr-NK-1R isoform is expressed essentially among the different subsets of $\mathrm{HB}$ and it seems that this isoform is associated with cancer rather than the full-length isoform. It seems that HB cells have no possibility of becoming resistant to NK-1R antagonists since in $\mathrm{HB}$ cells the tr-NK-1R isoform is continuously up-regulated (the truncated isoform could be responsible for a constitutive growth stimulus) and, for this reason, the antitumor effect of the NK-1R antagonists is linked to the differential expression of the NK-1R (truncated and full isoforms) in cancer cells. In combination therapy, NK-1R antagonists (show no severe side-effects) and cytostatics produce an antitumor synergistic effect against the HB cells (this is important in order to decrease the concentration of cytostatics in clinical practice), decrease the toxicity of chemotherapeutics and increase the sensitivity of the HB cells to cytostatics. Since aprepitant targets two crucial pathways involved in tumorigenesis (PI3K/Akt/mTOR and Wnt), NK-1R antagonists could more easily block escape mechanisms in the HB cells and decrease HB relapse/resistance. In summary, NK-1R is a new marker and target for the treatment of HB and NK-1R antagonists exert an antitumor/antiangiogenic action against $\mathrm{HB}$.

Author Contributions: All the authors contributed equally to the work.

Funding: This research was funded by “Programa XI: Financiación de Unidades de Excelencia de la Universidad de Salamanca" (Spain).

Acknowledgments: The authors wish to thank Javier Muñoz (University of Sevilla, Spain) for technical assistance and Diane Haun (University of Utah, USA) for reviewing the English.

Conflicts of Interest: USPTO Application no. 20090012086 “Use of non-peptidic NK-1 receptor antagonists for the production of apoptosis in tumor cells" (Miguel Muñoz). No conflict of interest (Marisa Rosso and Rafael Coveñas).

\section{References}

1. Stiller, C.A.; Pritchard, J.; Steliarova-Foucher, E. Liver cancer in European children: Incidence and survival, 1978-1997. Report from the Automated Childhood Cancer Information System project. Eur. J. Cancer 2006, 42, 2115-2123. [CrossRef] [PubMed]

2. Meyers, R.L.; Maibach, R.; Hiyama, E.; Häberle, B.; Krailo, M.; Rangaswami, A.; Aronson, D.C.; Malogolowkin, M.H.; Perilongo, G.; von Schweinitz, D.; et al. Risk-stratified staging in paediatric hepatoblastoma: A unified analysis from the children's hepatic tumors international collaboration. Lancet Oncol. 2017, 18, 122-131. [CrossRef]

3. Bell, D.; Ranganathan, S.; Tao, J.; Monga, S.P. Novel advances in understanding of molecular pathogenesis of hepatoblastoma: A Wnt/ $\beta$-catenin perspective. Gene Expr. 2017, 17, 141-154. [CrossRef] [PubMed]

4. Muñoz, M.; Coveñas, R. Involvement of substance P and the NK-1 receptor in cancer progression. Peptides 2013, 48, 1-9. [CrossRef] [PubMed]

5. Muñoz, M.; Rosso, M.; Robles-Frías, M.J.; Salinas-Martín, M.V.; Coveñas, R. The NK-1 receptor is expressed in human melanoma and is involved in the antitumor action of the NK-1 receptor antagonist aprepitant on melanoma cell lines. Lab. Investig. 2010, 90, 1259-1269. [CrossRef] [PubMed]

6. Berger, M.; Neth, O.; Ilmer, M.; Garnier, A.; Salinas-Martín, M.V.; de Agustin Asencio, J.C.; von Schweinitz, D.; Kappler, R.; Muñoz, M. Hepatoblastoma cells express truncated neurokinin-1 receptor and can be growth inhibited by aprepitant in vitro and in vivo. J. Hepatol. 2014, 60, 985-994. [CrossRef] [PubMed]

7. Muñoz, M.; Coveñas, R.; Esteban, F.; Redondo, M. The substance P/NK-1 receptor system: NK-1 receptor antagonists as anti-cancer drugs. J. Biosci. 2015, 40, 441-463. [CrossRef] 
8. Roush, E.D.; Kwatra, M.M. Human substance P receptor expressed in Chinese hamster ovary cells directly activates g (alpha q/11), g (alpha s), g (alpha o). FEBS Lett. 1998, 428, 291-294. [CrossRef]

9. Mitsuhashi, M.; Ohashi, Y.; Shichijo, S.; Christian, C.; Sudduth-Klinger, J.; Harrowe, G.; Payan, D.G. Multiple intracellular signaling pathways of the neuropeptide substance P receptor. J. Neurosci. Res. 1992, 32, 437-443. [CrossRef]

10. Sagan, S.; Chassaing, G.; Pradier, L.; Lavielle, S. Tachykinin peptides affect differently the second messenger pathways after binding to CHO-expressed human NK-1 receptors. J. Pharmacol. Exp. Ther. 1996, 276, 1039-1048.

11. Takeda, Y.; Blount, P.; Sachais, B.S.; Hershey, A.D.; Raddatz, R.; Krause, J.E. Ligand binding kinetics of substance $\mathrm{P}$ and neurokinin A receptors stably expressed in Chinese hamster ovary cells and evidence for differential stimulation of inositol 1, 4, 5 trisphosphate and cyclic amp second messenger responses. J. Neurochem. 1992, 59, 740-745. [CrossRef]

12. Garnier, A.; Ilmer, M.; Kappler, R.; Berger, M. Therapeutic innovations for targeting hepatoblastoma. Anticancer Res. 2016, 36, 5577-5592. [CrossRef]

13. Ramkissoon, S.H.; Patel, H.J.; Taborga, M.; Rameshwar, P. G protein-coupled receptors in haematopoietic disruption. Expert Opin. Biol. Ther. 2006, 6, 109-120. [CrossRef]

14. Nakajima, Y.; Tsuchida, K.; Negishi, M.; Ito, S.; Nakanishi, S. Direct linkage of three tachykinin receptors to stimulation of both phosphatidylinositol hydrolysis and cyclic AMP cascades in transfected Chinese hamster ovary cells. J. Biol. Chem. 1992, 267, 2437-2442.

15. Holst, B.; Hastrup, H.; Raffetseder, U.; Martini, L.; Schwartz, T.W. Two active molecular phenotypes of the tachykinin NK1 receptor revealed by G-protein fusions and mutagenesis. J. Biol. Chem. 2001, 276, 19793-19799. [CrossRef]

16. Khawaja, A.M.; Rogers, D.F. Tachykinins: Receptor to effector. Int. J. Biochem. Cell Biol. 1996, 28, 721-738. [CrossRef]

17. Pennefather, J.N.; Lecci, A.; Candenas, M.L.; Patak, E.; Pinto, F.M.; Maggi, C.A. Tachykinins and tachykinin receptors: A growing family. Life Sci. 2004, 74, 1445-1463. [CrossRef]

18. Kage, R.; Leeman, S.E.; Krause, J.E.; Costello, C.E.; Boyd, N.D. Identification of methionine as the site of covalent attachment of a p-benzoyl-phenylalanine-containing analogue of substance $\mathrm{P}$ on the substance $\mathrm{P}$ (NK-1) receptor. J. Biol. Chem. 1996, 271, 25797-25800. [CrossRef]

19. Mantyh, P.W.; Allen, C.J.; Ghilardi, J.R.; Rogers, S.D.; Mantyh, C.R.; Liu, H.; Basbaum, A.I.; Vigna, S.R.; Maggio, J.E. Rapid endocytosis of a G protein-coupled receptor: Substance P evoked internalization of its receptor in the rat striatum in vivo. Proc. Natl. Acad. Sci. USA 1995, 92, 2622-2626. [CrossRef]

20. Roosterman, D.; Cottrell, G.S.; Schmidlin, F.; Steinhoff, M.; Bunnett, N.W. Recycling and resensitization of the neurokinin 1 receptor. Influence of agonist concentration and Rab GTPases. J. Biol. Chem. 2004, 279, 30670-30679. [CrossRef]

21. DeFea, K.A.; Vaughn, Z.D.; O’Bryan, E.M.; Nishijima, D.; Déry, O.; Bunnett, N.W. The proliferative and antiapoptotic effects of substance $\mathrm{P}$ are facilitated by formation of a beta-arrestin-dependent scaffolding complex. Proc. Natl. Acad. Sci. USA 2000, 97, 11086-11091. [CrossRef]

22. Fong, T.M.; Anderson, S.A.; Yu, H.; Huang, R.R.; Strader, C.D. Differential activation of intracellular effector by two isoforms of human neurokinin-1 receptor. Mol. Pharmacol. 1992, 41, 24-30.

23. Page, N.M. New challenges in the study of the mammalian tachykinins. Peptides 2005, 26, 1356-1368. [CrossRef]

24. Li, H.; Leeman, S.E.; Slack, B.E.; Hauser, G.; Saltsman, W.S.; Krause, J.E.; Blusztajn, J.K.; Boyd, N.D. A substance $\mathrm{P}$ (neurokinin-1) receptor mutant carboxyl-terminally truncated to resemble a naturally occurring receptor isoform displays enhanced responsiveness and resistance to desensitization. Proc. Natl. Acad. Sci. USA 1997, 94, 9475-9480. [CrossRef]

25. Douglas, S.D.; Leeman, S.E. Neurokinin-1 receptor: Functional significance in the immune system in reference to selected infections and inflammation. Ann. N. Y. Acad. Sci. 2010, 1217, 83-95. [CrossRef]

26. Muñoz, M.; González-Ortega, A.; Rosso, M.; Robles-Frías, M.J.; Carranza, A.; Salinas-Martín, M.V.; Coveñas, R. The substance P/neurokinin-1 receptor system in lung cancer: Focus on the antitumor action of neurokinin-1 receptor antagonists. Peptides 2012, 38, 318-325. [CrossRef]

27. Friess, H.; Zhu, Z.; Liard, V.; Shi, X.; Shrikhande, S.V.; Wang, L.; Lieb, K.; Korc, M.; Palma, C.; Zimmermann, A.; et al. Neurokinin-1 receptor expression and its potential effects on tumor growth in human pancreatic cancer. Lab. Investig. 2003, 83, 731-742. [CrossRef] 
28. Hennig, I.M.; Laissue, J.A.; Horisberger, U.; Reubi, J.C. Substance-P receptors in human primary neoplasms: Tumoral and vascular localization. Int. J. Cancer 1995, 61, 786-792. [CrossRef]

29. Singh, D.; Joshi, D.D.; Hameed, M.; Qian, J.; Gascón, P.; Maloof, P.B.; Mosenthal, A.; Rameshwar, P. Increased expression of preprotachykinin-I and neurokinin receptors in human breast cancer cells: Implications for bone marrow metastasis. Proc. Natl. Acad. Sci. USA 2000, 97, 1388-1393. [CrossRef]

30. Zhou, Y.; Zhao, L.; Xiong, T.; Chen, X.; Zhang, Y.; Yu, M.; Yang, J.; Yao, Z. Roles of full-length and truncated neurokinin-1 receptors on tumor progression and distant metastasis in human breast cancer. Breast Cancer Res. Treat. 2013, 140, 49-61. [CrossRef]

31. Davoodian, M.; Boroumand, N.; Mehrabi Bahar, M.; Jafarian, A.H.; Asadi, M.; Hashemy, S.I. Evaluation of serum level of substance P and tissue distribution of NK-1 receptor in breast cancer. Mol. Biol. Rep. 2019, 46, 1285-1293. [CrossRef]

32. Garnier, A.; Ilmer, M.; Becker, K.; Häberle, B.; von Schweinitz, D.; Kappler, R.; Berger, M. Truncated neurokinin-1 receptor is an ubiquitous antitumor target in hepatoblastoma, and its expression is independent of tumor biology and stage. Oncol. Lett. 2016, 11, 870-878. [CrossRef]

33. Muñoz, M.; Berger, M.; Rosso, M.; González-Ortega, A.; Carranza, A.; Coveñas, R. Antitumor activity of neurokinin-1 receptor antagonists in MG-63 human osteosarcoma xenografts. Int. J. Oncol. 2014, 44, 137-146. [CrossRef]

34. Luo, W.; Sharif, T.R.; Sharif, M. Substance P-induced mitogenesis in human astrocytoma cells correlates with activation of the mitogen-activated protein kinase signaling pathway. Cancer Res. 1995, 56, 4983-4991.

35. Shibuya, H.; Yoneyama, M.; Ninomiya-Tsuji, J.; Matsumoto, K.; Taniguchi, T. IL-2 and EGF and EGF receptors stimulate the hematopoietic cell cycle via different signaling pathways: Demonstration of a novel role for c-myc. Cell 1992, 70, 57-67. [CrossRef]

36. Wang, H.; Lu, J.; Edmunds, L.R.; Kulkarni, S.; Dolezal, J.; Tao, J.; Ranganathan, S.; Jackson, L.; Fromherz, M.; Beer-Stolz, D.; et al. Coordinated activities of multiple myc-dependent and myc-independent biosynthetic pathways in hepatoblastoma. J. Biol. Chem. 2016, 291, 26241-26251. [CrossRef]

37. Castagliuolo, I.; Valenick, L.; Liu, J.; Pothoulakis, C. Epidermal growth factor receptor transactivation mediates substance P-induced mitogenic responses in U-373 MG cells. J. Biol. Chem. 2000, 275, 26545-26550. [CrossRef]

38. Almendro, V.; García-Recio, S.; Gascón, P. Tyrosine kinase receptor transactivation associated to G protein-coupled receptors. Curr. Drug Targets 2010, 11, 1169-1180. [CrossRef]

39. Molina, L.; Yang, H.; Adebayo Michael, A.O.; Oertel, M.; Bell, A.; Singh, S.; Chen, X.; Tao, J.; Monga, S.P.S. mTOR inhibition affects Yap1- $\beta$-catenin-induced hepatoblastoma growth and development. Oncotarget 2019, 10, 1475-1490. [CrossRef]

40. Bockmann, S.; Seep, J.; Jonas, L. Delay of neutrophil apoptosis by the neuropeptide substance P: Involvement of caspase cascade. Peptides 2001, 22, 661-670. [CrossRef]

41. Koon, H.W.; Zhao, D.; Zhan, Y.; Moyer, M.P.; Pothoulakis, C. Substance P mediates antiapoptotic responses in human colonocytes by Akt activation. Proc. Natl. Acad. Sci. USA 2007, 104, 2013-2018. [CrossRef]

42. Lim, J.E.; Chung, E.; Son, Y. A neuropeptide, substance-P, directly induces tissue-repairing M2 like macrophages by activating the PI3K/Akt/mTOR pathway even in the presence of IFN $\gamma$. Sci. Rep. 2017, 7, 9417. [CrossRef]

43. Hartmann, W.; Küchler, J.; Koch, A.; Friedrichs, N.; Waha, A.; Endl, E.; Czerwitzki, J.; Metzger, D.; Steiner, S.; Wurst, P.; et al. Activation of phosphatidylinositol-3'-kinase/AKT signaling is essential in hepatoblastoma survival. Clin. Cancer Res. 2009, 15, 4538-4545. [CrossRef]

44. Ilmer, M.; Garnier, A.; Vykoukal, J.; Alt, E.; von Schweinitz, D.; Kappler, R.; Berger, M. Targeting the neurokinin-1 receptor compromises canonical Wnt signaling in hepatoblastoma. Mol. Cancer Ther. 2015, 14, 2712-2721. [CrossRef]

45. Martelli, A.M.; Tabellini, G.; Bressanin, D.; Ognibene, A.; Goto, K.; Cocco, L.; Evangelisti, C. The emerging multiple roles of nuclear AKT. Biochim. Biophys. Acta 2012, 1823, 2168-2178. [CrossRef]

46. Breuleux, M.; Klopfenstein, M.; Stephan, C.; Doughty, C.A.; Barys, L.; Maira, S.M.; Kwiatkowski, D.; Lane, H.A. Increased AKT s473 phosphorylation after mTORC1 inhibition is rictor dependent and does not predict tumor cell response to PI3K/mTOR inhibition. Mol. Cancer Ther. 2009, 8, 742-753. [CrossRef] 
47. Chen, K.F.; Chen, H.L.; Tai, W.T.; Feng, W.C.; Hsu, C.H.; Chen, P.J.; Cheng, A.L. Activation of phosphatidylinositol 3-kinase/AKT signaling pathway mediates acquired resistance to sorafenib in hepatocellular carcinoma cells. J. Pharmacol. Exp. Ther. 2011, 337, 155-161. [CrossRef]

48. Yun, M.S.; Kim, S.E.; Jeon, S.H.; Lee, J.S.; Choi, K.Y. Both ERK and Wnt/beta-catenin pathways are involved in Wnt3a-induced proliferation. J. Cell Sci. 2005, 118, 313-322. [CrossRef]

49. Mei, G.; Xia, L.; Zhou, J.; Zhang, Y.; Tuo, Y.; Fu, S.; Zou, Z.; Wang, Z.; Jin, D. Neuropeptide SP activates the Wnt signal transduction pathway and enhances the proliferation of bone marrow stromal stem cells. Cell Biol. Int. 2013, 37, 1225-1232. [CrossRef]

50. Winn, R.A.; Bremnes, R.M.; Bemis, L.; Franklin, W.A.; Miller, Y.E.; Cool, C.; Heasley, L.E. Gamma-catenin expression is reduced or absent in a subset of human lung cancers and re-expression inhibits transformed cell growth. Oncogene 2002, 21, 7497-7506. [CrossRef]

51. Fu, S.; Jin, D.; Liu, S.; Wang, L.; Wang, Z.; Mei, G.; Zou, Z.L.; Wu, J.Q.; Xu, Z.Y. Protective effect of neuropeptide substance $\mathrm{P}$ on bone marrow mesenchymal stem cells against apoptosis induced by serum deprivation. Stem Cells Int. 2015, 2015, 270328. [CrossRef]

52. Zhang, N.; Wei, P.; Gong, A.; Chiu, W.T.; Lee, H.T.; Colman, H.; Huang, H.; Xue, J.; Liu, M.; Wang, Y.; et al. Foxm1 promotes beta-catenin nuclear localization and controls Wnt target-gene expression and glioma tumorigenesis. Cancer Cell 2011, 20, 427-442. [CrossRef]

53. Yu, Y.; Ramena, G.; Elble, R.C. The role of cancer stem cells in relapse of solid tumors. Front. Biosci. 2012, 4, 1528-1541. [CrossRef]

54. Harrison, S.; Geppetti, P. Substance P. Int. J. Biochem. Cell Biol. 2001, 33, 555-576. [CrossRef]

55. Hökfelt, T.; Pernow, B.; Wahren, J. Substance P: A pioneer amongst neuropeptides. J. Intern. Med. 2001, 249, 27-40. [CrossRef]

56. Esteban, F.; Muñoz, M.; González-Moles, M.A.; Rosso, M. A role for substance P in cancer promotion and progression: A mechanism to counteract intracellular death signals following oncogene activation or DNA damage. Cancer Metastasis Rev. 2006, 25, 137-145. [CrossRef]

57. Akazawa, T.; Kwatra, S.G.; Goldsmith, L.E.; Richardson, M.D.; Cox, E.A.; Sampson, J.H.; Kwatra, M.M. A constitutively active form of neurokinin 1 receptor and neurokinin 1 receptor-mediated apoptosis in glioblastomas. J. Neurochem. 2009, 109, 1079-1086. [CrossRef]

58. Wang, J.G.; Yu, J.; Hu, J.L.; Yang, W.L.; Ren, H.; Ding, D.; Zhang, L.; Liu, X.P. Neurokinin-1activation affects EGFR related signal transduction in triple negative breast cancer. Cell Signal. 2015, 27, 1315-1324. [CrossRef]

59. Warburg, O. On the origin of cancer cells. Science 1956, 123, 309-314. [CrossRef]

60. Medrano, S.; Gruenstein, E.; Dimlich, R.V. Substance P receptors on human astrocytoma cells are linked to glycogen breakdown. Neurosci. Lett. 1994, 167, 14-18. [CrossRef]

61. Ougolkov, A.V.; Fernández-Zapico, M.E.; Savoy, D.N.; Urrutia, R.A.; Billadeau, D.D. Glycogen synthase kinase-3beta participates in nuclear factor kappaB-mediated gene transcription and cell survival in pancreatic cancer cells. Cancer Res. 2005, 65, 2076-2081. [CrossRef]

62. Zeng, J.; Liu, D.; Qiu, Z.; Huang, Y.; Chen, B.; Wang, L.; Xu, H.; Huang, N.; Liu, L.; Li, W. GSK3 $\beta$ overexpression indicates poor prognosis and its inhibition reduces cell proliferation and survival of non-small cell lung cancer cells. PLoS ONE 2014, 9, e91231. [CrossRef]

63. Wiedermann, C.J.; Auer, B.; Sitte, B.; Reinisch, N.; Schratzberger, P.; Kähler, C.M. Induction of endothelial cell differentiation into capillary-like structures by substance P. Eur. J. Pharmacol. 1996, 298, 335-338. [CrossRef]

64. Ho, W.Z.; Lai, J.P.; Zhu, X.H.; Uvaydova, M.; Douglas, S.D. Human monocytes and macrophages express substance P and neurokinin-1 receptor. J. Immunol. 1997, 159, 5654-5660.

65. Walsh, D.A.; Hu, D.E.; Mapp, P.I.; Polak, J.M.; Blake, D.R.; Fan, T.P. Innervation and neurokinin receptors during angiogenesis in the rat sponge granuloma. Histochem. J. 1996, 28, 759-769. [CrossRef]

66. Ziche, M.; Morbidelli, L.; Pacini, M.; Gepetti, P.; Alessandri, G.; Maggi, C.A. Substance P stimulates neovascularization in vivo and proliferation of cultured endothelial cells. Microvasc. Res. 1990, 40, 264-278. [CrossRef]

67. Theoharides, T.C.; Zhang, B.; Kempuraj, D.; Tagen, M.; Vasiadi, M.; Angelidou, A.; Alysandratos, K.D.; Kalogeromitros, D.; Asadi, S.; Stavrianeas, N.; et al. IL-33 augments substance P-induced VEGF secretion from human mast cells and is increased in psoriatic skin. Proc. Natl. Acad. Sci. USA 2010, 107, 4448-4453. [CrossRef] 
68. Guha, S.; Eibl, G.; Kisfalvi, K.; Fan, R.S.; Burdick, M.; Reber, H.; Hines, O.J.; Strieter, R.; Rozengurt, E. Broad-spectrum G protein-coupled receptor antagonist, [D-Arg1, DTrp5,7,9, Leu11] SP: A dual inhibitor of growth and angiogenesis in pancreatic cancer. Cancer Res. 2005, 65, 2738-2745. [CrossRef]

69. Fackler, O.T.; Grosse, R. Cell motility through plasma membrane blebbing. J. Cell Biol. 2008, 181, 879-884. [CrossRef]

70. Lang, K.; Drell, T.L.; Lindecke, A.; Niggemann, B.; Kaltschmidt, C.; Zaenker, K.S.; Entschladen, F. Induction of a metastatogenic tumor cell type by neurotransmitters and its pharmacological inhibition by established drugs. Int. J. Cancer 2004, 112, 231-238. [CrossRef]

71. Ma, J.; Yuan, S.; Cheng, J.; Kang, S.; Zhao, W.; Zhang, J. Substance P promotes the progression of endometrial adenocarcinoma. Int. J. Gynecol. Cancer 2016, 26, 845-850. [CrossRef]

72. Meshki, J.; Douglas, S.D.; Lai, J.P.; Schwartz, L.; Kilpatrick, L.E.; Tuluc, F. Neurokinin 1 receptor mediates membrane blebbing in HEK293 cells through a Rho/Rho-associated coiled-coil kinase-dependent mechanism. J. Biol. Chem. 2009, 284, 9280-9289. [CrossRef]

73. Meshki, J.; Douglas, S.D.; Hu, M.; Leeman, S.E.; Tuluc, F. Substance P induces rapid and transient membrane blebbing in U373MG cells in a p21-activated kinase-dependent manner. PLoS ONE 2011, 6, e25332. [CrossRef]

74. Ranganathan, S.; Ningappa, M.; Ashokkumar, C.; Higgs, B.W.; Min, J.; Sun, Q.; Schmitt, L.; Subramaniam, S.; Hakonarson, H.; Sindhi, R. Loss of EGFR-ASAP1 signaling in metastatic and unresectable hepatoblastoma. Sci. Rep. 2016, 6, 38347. [CrossRef]

75. Marín, J.J.G.; Cives-Losada, C.; Asensio, M.; Lozano, E.; Briz, O.; Macías, R.I.R. Mechanisms of anticancer drug resistance in hepatoblastoma. Cancers 2019, 11, 407. [CrossRef]

76. Herzog, C.E.; Andrassy, R.J.; Eftekhari, F. Childhood cancers: Hepatoblastoma. Oncologist 2000, 5, 445-453. [CrossRef]

77. Ichikawa, Y.; Ghanefar, M.; Bayeva, M.; Wu, R.; Khechaduri, A.; Naga Prasad, S.V.; Mutharasan, R.K.; Naik, T.J.; Ardehali, H. Cardiotoxicity of doxorubicin is mediated through mitochondrial iron accumulation. J. Clin. Investig. 2014, 124, 617-630. [CrossRef]

78. Robinson, P.; Kasembeli, M.; Bharadwaj, U.; Engineer, N.; Eckols, K.T.; Tweardy, D.J. Substance P receptor signaling mediates doxorubicin-induced cardiomyocyte apoptosis and triple-negative breast cancer chemoresistance. BioMed Res. Int. 2016, 2016, 1959270. [CrossRef]

79. Kitchens, C.A.; McDonald, P.R.; Pollack, I.F.; Wipf, P.; Lazo, J.S. Synergy between microtubule destabilizing agents and neurokinin 1 receptor antagonists identified by an siRNA synthetic lethal screen. FASEB J. 2009, $23,756$.

80. Muñoz, M.; Crespo, J.C.; Crespo, J.P.; Coveñas, R. The neurokinin-1 receptor antagonist aprepitant and radiotherapy: A successful combination therapy in a patient with lung cancer. Mol. Clin. Oncol. 2019, 11, 50-54.

81. Muñoz, M.; Parrilla, J.; Rosso, M.; Coveñas, R. Antipruritic vs. Antitumor action of aprepitant: A question of dose. Acta Derm. Venereol. 2019, 99, 620-621. [CrossRef]

82. Paul, B.; Trovato, J.A.; Thompson, J.; Badros, A.Z.; Goloubeva, O. Efficacy of aprepitant in patients receiving high-dose chemotherapy with hematopoietic stem cell support. J. Oncol. Pharm. Pract. 2010, 16, 45-51. [CrossRef]

83. Muñoz, M.; Coveñas, R. Safety of neurokinin-1 receptor antagonists. Expert Opin. Drug Saf. 2013, 12, $673-685$. [CrossRef]

84. Kramer, M.S.; Cutler, N.; Feighner, J.; Shrivastava, R.; Carman, J.; Sramek, J.J.; Reines, S.A.; Liu, G.; Snavely, D.; Wyatt-Knowles, E.; et al. Distinct mechanism for antidepressant activity by blockade of central substance P receptors. Science 1998, 281, 1640-1645. [CrossRef]

85. Molinos-Quintana, A.; Trujillo-Hacha, P.; Piruat, J.I.; Bejarano-García, J.A.; García-Guerrero, E.; Pérez-Simón, J.A.; Muñoz, M. Human acute myeloid leukemia cells express neurokinin-1 receptor, which is involved in the antileukemic effect of neurokinin-1 receptor antagonists. Investig. New Drugs. 2018, 37, 17-26. [CrossRef]

(C) 2019 by the authors. Licensee MDPI, Basel, Switzerland. This article is an open access article distributed under the terms and conditions of the Creative Commons Attribution (CC BY) license (http://creativecommons.org/licenses/by/4.0/). 